\title{
Distribution and variability of total mercury in snow cover-a case study from a semi-urban site in Poznań, Poland
}

\author{
Patrycja Siudek ${ }^{1}$
}

Received: 23 May 2016 / Accepted: 7 September 2016/Published online: 21 September 2016

(C) The Author(s) 2016. This article is published with open access at Springerlink.com

\begin{abstract}
In the present paper, the inter-seasonal $\mathrm{Hg}$ variability in snow cover was examined based on multivariate statistical analysis of chemical and meteorological data. Samples of freshly fallen snow cover were collected at the semi-urban site in Poznań (central Poland), during 3-month field measurements in winter 2013. It was showed that concentrations of atmospherically deposited $\mathrm{Hg}$ were highly variable in snow cover, from 0.43 to $12.5 \mathrm{ng} \mathrm{L}^{-1}$, with a mean value of $4.62 \mathrm{ng} \mathrm{L}^{-1}$. The highest $\mathrm{Hg}$ concentration in snow cover coincided with local intensification of fossil fuel burning, indicating large contribution from various anthropogenic sources such as commercial and domestic heating, power generation plants, and traffic-related pollution. Moreover, the variability of $\mathrm{Hg}$ in collected snow samples was associated with long-range transport of pollutants, nocturnal inversion layer, low boundary layer height, and relatively low air temperature. For three snow episodes, $\mathrm{Hg}$ concentration in snow cover was attributed to southerly advection, suggesting significant contribution from the highly polluted region of Poland (Upper Silesia) and major European industrial hotspots. However, the peak $\mathrm{Hg}$ concentration was measured in samples collected during predominant $\mathrm{N}$ to $\mathrm{NE}$ advection of polluted air masses and after a relatively longer period without precipitation. Such significant contribution to the higher $\mathrm{Hg}$ accumulation in snow cover was associated with intensive emission from anthropogenic sources (coal combustion) and atmospheric
\end{abstract}

Responsible editor: Philippe Garrigues

Patrycja Siudek

pat.s@amu.edu.pl

1 Department of Water and Soil Analysis, Faculty of Chemistry, Adam Mickiewicz University in Poznań, Umultowska Street 89b, 61-614 Poznań, Poland conditions in this area. These results suggest that further measurements are needed to determine how the $\mathrm{Hg}$ transformation paths in snow cover change in response to longer/shorter duration of snow cover occurrence and to determine the interactions between mercury and absorbing carbonaceous aerosols in the light of climate change.

Keywords Mercury · Snow cover · Urban · Anthropogenic · Emission

\section{Introduction}

Urban snow is a key parameter in hydrological, meteorological, and ecological non-linear processes in the environment (Engelhard et al. 2007). Mercury, as a highly toxic contaminant, can reinforce its negative impact on biotic and abiotic processes in aquatic and terrestrial ecosystems after snowmelt (Wiener et al. 2003). In-situ long-term measurements of gaseous elemental $\mathrm{Hg}$ (GEM) and its oxidized species (RGM, reactive gaseous mercury: HgP, particulate mercury) in the snowpack and overlaying atmosphere have been intensively undertaken over the past decade by various polar research groups in the Canadian Arctic, Antarctica, and Greenland. The unique phenomenon called atmospheric mercury depletion event (AMDE) is very promising scientific issue with regard to further researches on $\mathrm{Hg}$ atmospheric chemistry in polar regions (Lu et al. 2001, Witherow and Lyons 2008). It was observed that GEM can be removed during springtime from lower atmosphere via photochemical processes and rapidly deposited on the snow cover, resulting in extremely low values of GEM above the polar snowpack. Recent studies at polar sunrise revealed that total mercury concentrations in the 
surface snowpack are elevated, up to $100 \mathrm{ng} \mathrm{L}^{-1}$ (Lahoutifard et al. 2005, Larose et al. 2013), compared to other non-polar locations.

Despite clear evidence for $\mathrm{Hg}$ emission from the snowpack at high latitudes, similar mechanism in relation to lower latitudes (Europe and Northern America) has several uncertainties. Data on vertical distribution of $\mathrm{Hg}$ and its seasonal variability in the snow cover from nonpolar regions are limited. However, this subject has been investigated in Europe recently, for example, Siudek et al. (2014) observed a very irregular distribution pattern of $\mathrm{Hg}$ in the urban snowpack from Gdynia (northern Poland), with a maximum $\mathrm{Hg}$ concentration of $22.5 \mathrm{ng} \mathrm{L}^{-1}$. Measurements of $\mathrm{Hg}$ by Nelson et al. (2007) showed that intensive coal combustion in residential and commercial buildings during winter period caused high $\mathrm{Hg}$ concentrations in the snowpack from Maine, US. Faïn et al. (2007) and Ferrari et al. (2002) also found extremely high amount of mercury in alpine snow samples, suggesting the increasing trend in anthropogenic $\mathrm{Hg}$ emission during cold season. Mercury emission to the atmosphere during the heating season significantly affects snow cover properties and composition. The influence of urban environments on $\mathrm{Hg}$ processes in the air, water, and sediments is of crucial interest and depends on many factors such as site characteristics, emission rate, distance to anthropogenic sources, and meteorological background. (De Simone et al. 2014, Li et al. 2015, Liu et al. 2015, Siudek et al. 2015a). Although the main sources of $\mathrm{Hg}$ in the snowpack are well determined, the quantitative analysis of $\mathrm{Hg}$ in snow cover system may be of crucial importance to study processes such as transfer of $\mathrm{Hg}$ species from the overlaying air to snow and possible re-emission or retention of $\mathrm{Hg}$, and to better understand the impact of small-scale dynamics of $\mathrm{Hg}$ on the environment and air quality.

The present study was based on eight snow experiments carried out in an urban area of central Poland, in one winter season. The experiments were conducted to identify how particular factors connected with atmospheric conditions, i.e., air temperature, wind speed and direction, impact of local/regional, and remote emission sources, can influence retention of atmospheric mercury in shallow snow cover and to describe the role of $\mathrm{Hg}$ transformation processes inside the snow column. To achieve these aims, a combination of field measurements, chemometric techniques (PCA), and backward trajectory analysis (HYSPLIT model) was implemented. The role of other inorganic pollutants measured in snow cover was also considered. Therefore, the results from these experiments can be used for further modeling studies and chemical calculations to estimate the impact of $\mathrm{Hg}$ deposition with snow on the ecosystem of similar regions.

\section{Materials and Methods}

\section{Study area}

The city of Poznań, as an example of inland urban area, has been chosen for the present study on mercury in snow cover. Poznań (city area $261.8 \mathrm{~km}^{2}$, inhabitants of up to 600,000 ) is located in the Wielkopolska Province, central Poland. It is influenced by various industrial and urban emission sources (diurnal and/or seasonal time scale). Main $\mathrm{Hg}$ sources include the following: coal-burning heat and power plants, individual power generating stations and domestic furnaces where coal is the main fossil fuel, residential and domestic buildings, dumping grounds for municipal wastes, domestic sewage, cement factories, sewage treatment plants, airport infrastructure, transportation, different industrial units producing metals and paints, and high-temperature industrial processes (smelting, waste incineration).

The climate in central Poland is temperate, with annual mean temperature of about $8.5^{\circ} \mathrm{C}$, frequent precipitation events, and prevailing wind direction from the northwest. Poznań has the lowest yearly sum of precipitation in Poland $(<550 \mathrm{~mm})$ and $32 \%$ of falls occurs during winter season. In this region, the number of days with snow cover and air temperatures below $0{ }^{\circ} \mathrm{C}$ is relatively low as compared with high mountains or poles. Snow cover typically occurs between November and late March. Its composition is strongly affected by atmospheric conditions (advection of polluted air masses, city heat island), snowpack processes (compaction, heat conduction, turbulent fluxes), soil and air temperature, and liquid water content. Thus, the occurrence and amount of snow may significantly vary both spatially and temporally, even within a single winter season. In the present study, the average time for individual snow cover ( $\min .5 \mathrm{~cm}$ ) formation ranged from 10 to $24 \mathrm{~h}$ and depended highly on specific meteorological patterns. Table 1 presents data for each snow event and its meteorological background. Snow experiments were divided according to the month of sampling, i.e., J-snow experiments that were performed in January (two case studies), F-snow samples collected in February (three case studies), and Msnow cover sampled in March (three case studies). Such classification has been applied to indicate major factors (seasonal and meteorological) influencing $\mathrm{Hg}$ variability in snow cover.

\section{Sampling method}

Snow experiments were conducted at the semi-urban site $\left(52^{\circ}\right.$ $\left.42^{\prime} \mathrm{N}, 16^{\circ} 88^{\prime} \mathrm{E}\right)$, in January, February, and March, 2013. The sampling site, located at the Adam Mickiewicz University campus in Morasko, is approximately $10 \mathrm{~km}$ north of Poznań city center (Fig. 1). Previous aerosol-related measurements in this area provided a synthetic report of most significant local and regional trace metal emission sources, i.e., fuel 
Table 1 Statistical characteristics of atmospheric conditions in Poznań during the sampling days in winter 2013

\begin{tabular}{|c|c|c|c|c|c|c|c|c|}
\hline Code & Date & $\begin{array}{l}\text { Snow } \\
\text { cover } \\
\text { depth }(\mathrm{cm})\end{array}$ & $\begin{array}{l}\text { Number of } \\
\text { snow layers }\end{array}$ & $\begin{array}{l}\text { Mean } \\
\text { temperature } \pm \\
\text { SD (min-max) }\end{array}$ & $\begin{array}{l}\text { Mean relative } \\
\text { humidity } \pm \mathrm{SD} \\
(\min -\max )\end{array}$ & $\begin{array}{l}\text { Mean } \\
\text { pressure } \pm \mathrm{SD} \\
(\min -\max )\end{array}$ & $\begin{array}{l}\text { Mean wind } \\
\text { speed } \pm \text { SD } \\
(\min -\max )\end{array}$ & $\begin{array}{l}\text { Prevailing } \\
\text { wind direction }\end{array}$ \\
\hline $\mathrm{J} 1$ & $25 / 01$ & 15 & 11 & $\begin{array}{l}-6.6 \pm 4.0 \\
-12.4 \text { to }-0.2\end{array}$ & $\begin{array}{l}93 \pm 8.5 \\
75-95\end{array}$ & $\begin{array}{l}1011 \pm 1.2 \\
(1008-1012)\end{array}$ & $\begin{array}{l}0.2 \pm 0.3 \\
(0.1-1.1)\end{array}$ & $\mathrm{N}, \mathrm{NE}$ \\
\hline $\mathrm{J} 2$ & $28 / 01$ & 10 & 9 & $\begin{array}{l}-2.9 \pm 2.2 \\
-6 \text { to }-0.2\end{array}$ & $\begin{array}{l}97 \pm 1.6 \\
92-98\end{array}$ & $\begin{array}{l}1001 \pm 3.4 \\
(996-1005)\end{array}$ & $\begin{array}{l}1 \pm 0.3 \\
(0.6-2)\end{array}$ & NW, W \\
\hline $\mathrm{F} 1$ & $13 / 02$ & 6 & 5 & $\begin{array}{l}1.1 \pm 1.4 \\
-0.7 \text { to } 3.3\end{array}$ & $\begin{array}{l}89 \pm 11.2 \\
70-98\end{array}$ & $\begin{array}{l}1004 \pm 0.9 \\
(1002-1005)\end{array}$ & $\begin{array}{l}0.7 \pm 0.2 \\
(0.5-1.4)\end{array}$ & $\mathrm{S}, \mathrm{SE}$ \\
\hline $\mathrm{F} 2$ & $14 / 02$ & 10 & 10 & $\begin{array}{l}-0.4 \pm 0.9 \\
-1.9 \text { to } 3.4\end{array}$ & $\begin{array}{l}98 \pm 0.2 \\
97-98\end{array}$ & $\begin{array}{l}1014 \pm 1.9 \\
(1011-1016)\end{array}$ & $\begin{array}{l}0.3 \pm 0.3 \\
(0.2-1.1)\end{array}$ & SE, E \\
\hline F3 & $19 / 02$ & 12 & 11 & $\begin{array}{l}-0.5 \pm 0.5 \\
-1.2 \text { to } 1.6\end{array}$ & $\begin{array}{l}98 \pm 1.0 \\
94-98\end{array}$ & $\begin{array}{l}1010 \pm 2.9 \\
(1004-1014)\end{array}$ & $\begin{array}{l}1.4 \pm 0.5 \\
(0.6-2.2)\end{array}$ & NW, W \\
\hline M1 & $11 / 03$ & 20 & 13 & $\begin{array}{l}-2.9 \pm 0.6 \\
-3.8 \text { to }-2.0\end{array}$ & $\begin{array}{l}90 \pm 6.8 \\
81-98\end{array}$ & $\begin{array}{l}995 \pm 2.0 \\
(991-997)\end{array}$ & $\begin{array}{l}0.2 \pm 0.7 \\
(0.1-2.4)\end{array}$ & NE, E, SE \\
\hline M2 & $19 / 03$ & 25 & 16 & $\begin{array}{l}0.1 \pm 3.1 \\
-4.7 \text { to } 4.5\end{array}$ & $\begin{array}{l}56 \pm 10.0 \\
43-74\end{array}$ & $\begin{array}{l}1006 \pm 2.7 \\
(1002-1010)\end{array}$ & $\begin{array}{l}2.5 \pm 0.7 \\
(1.1-3.7)\end{array}$ & $\mathrm{S}, \mathrm{SE}$ \\
\hline M3 & $25 / 03$ & 20 & 14 & $\begin{array}{l}-3.3 \pm 5.9 \\
-13.7 \text { to } 2.2\end{array}$ & $\begin{array}{l}73 \pm 17.4 \\
50-98\end{array}$ & $\begin{array}{l}1016 \pm 0.9 \\
(1015-1018)\end{array}$ & $\begin{array}{l}0.5 \pm 0.4 \\
(0.1-1.5)\end{array}$ & NE, E \\
\hline
\end{tabular}

combustion, industrial processes, and heavy traffic (Siudek et al. 2015b, 2016). The surrounding area located to the southeast from the study domain is industrially impacted and significantly contributes to air pollution, while the northern sector represents mainly forests, rural, and sub-urban areas. It has been indicated that various anthropogenic sources have the impact on air quality in Poznań and adjacent areas; however, in winter, coal combustion in local domestic heating units (DHUs) plays a predominant role. Large $\mathrm{Hg}$ point sources are located within 10-20 km from the sampling site, e.g., CFFPs Poznań Karolin and metallurgical factory-about $5 \mathrm{~km}$ to the southeast; residential boilers, waste incinerations,
Biedrusko military area — about $10 \mathrm{~km}$ to the north; rail freight transport and roads - about $1 \mathrm{~km}$ to the south.

To obtain highly representative data, special precautions were undertaken. We selected a flat terrain, far from buildings, with several trees around. A special open system $(1 \times 1 \times 0.3 \mathrm{~m}$ PTEF-coated cuvette $)$ was installed to prevent snow cover from possible negative artifacts, i.e., from dust deposition on freshly fallen snow cover, diffusion and wind pumping effects, snow drifting, or snow blowing. Samples were taken after each snow event, within no longer than $12 \mathrm{~h}$ of snow cover formation. A full set of meteorological and physical measurements was performed at the sampling
Fig. 1 Map of the sampling site - a semi-urban area, Poznań, Poland

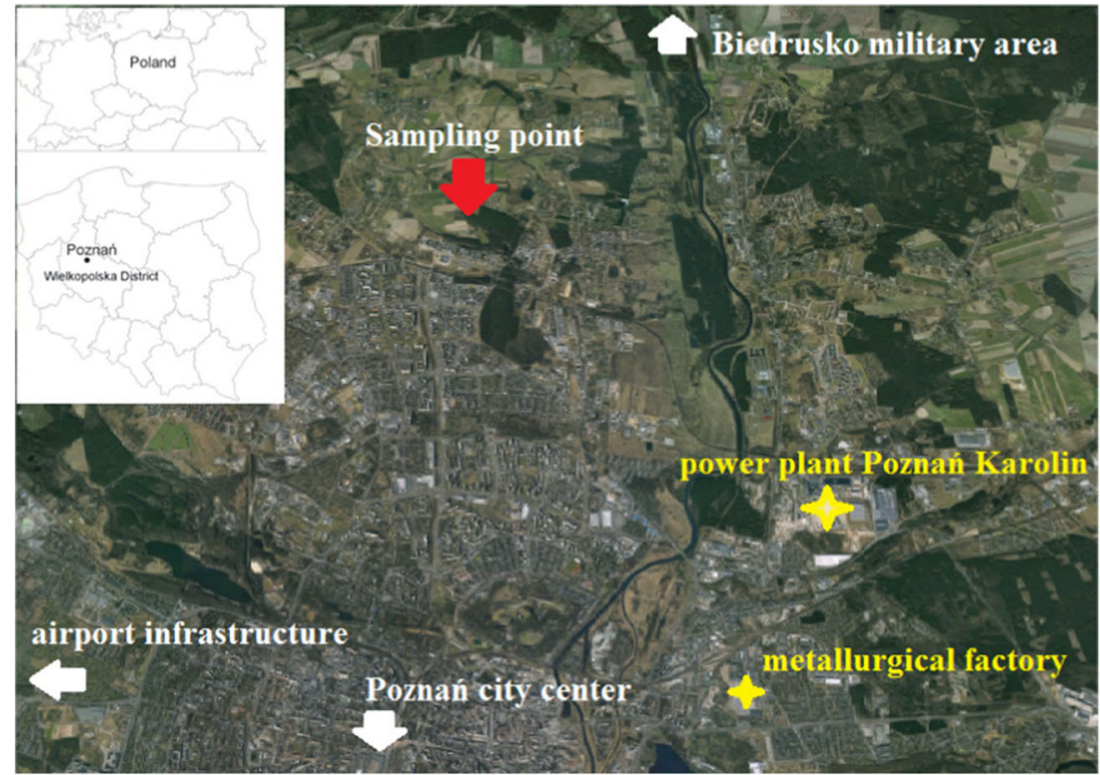


site. Specifically, we measured snow cover depth through the use of a polyethylene stick. The key step in our sampling method was to perform in-situ separation of snow layers. Each snowpack was divided into several subsamples (1-, 2-, 3 -cm layers). Snow layers were carefully separated from the whole column (starting from the snow surface, i.e., snow-air interface) and placed in pre-cleaned bottles. Then, all samples were transported to the laboratory. Snow sublayers were separated through the use of a pre-cleaned Plexiglas device and plate. Acid-cleaned borosilicate glass bottles and powder-free gloves were used to avoid sample contamination. A more detailed description of the adopted method can be found in Siudek et al. (2014). In the present study, we collected samples from at least 5 -cm snow cover, for which the in-situ separation of snow layer was much easy and therefore provide better accuracy of $\mathrm{Hg}$ determination.

After snow melting (in closed bottles), $30 \mathrm{ml}$ of a nonfiltered aliquot (homogenized by shaking) was acidified with trace element grade $\mathrm{HNO}_{3}(0.5 \% v / v$, Sigma Aldrich) to $\mathrm{pH}<2$ and stored for less than 2 weeks to the main analysis. The applied procedure (without filtration) ensures minimal loss of $\mathrm{Hg}$ species in snow samples. Lab glassware used in all snow experiments (bottles, plates) was rigorously acidsoaked in $3 \mathrm{M} \mathrm{HNO}_{3}$ for 1 week and then rinsed 5 times with double distilled water (DDW), dried under laminar flow in a clean bench, and stored in polyethylene bags.

Total $\mathrm{Hg}$ concentrations (dissolved and particulate fractions) in melted and non-filtered snow samples were analyzed by cold vapor atomic fluorescence spectrometry (CVAFS) on PSA Millennium Merlin mercury analyzer (UK), according to the standard method for Hg (US EPA method 1631 2002). In general, the above-mentioned analytical procedure is based on gold amalgamation and atomic fluorescence detection. Prior to the sample analysis, all $\mathrm{Hg}$ species were oxidized with $\mathrm{BrCl}$, neutralized with $\mathrm{NH}_{2} \mathrm{OH} \cdot \mathrm{HCl}$ solution, and then reduced with $\mathrm{SnCl}_{2}$. Laboratory analysis of bottles (every 10 rigorously acid-washed borosilicate glass bottles) and field blanks (snow corer rinsed with DDW) was performed prior to the main analysis. The bottle blanks were processed in parallel to the environmental samples, and their mean $\mathrm{Hg}$ values were below the detection limit, indicating that no contamination occurred during the collection, handling, transport, and storage of snow samples. Precision and accuracy of $\mathrm{Hg}$ measurements in snow samples were determined based on standard deviation and the mean value of triplicate analysis of spiked standard solutions. The relative percentage of differences (RSD) for samples did not exceed $5 \%$. The standard stock solution of $1000 \mathrm{mg} \mathrm{L}^{-1} \mathrm{Hg}$ in $\mathrm{HNO}_{3}$ was used to prepare five sub-standards $0.1,0.5,1.0,2.5$, and $5 \mathrm{ng}(1.0$, 5.0, 10.0, 25.0 and $50.0 \mathrm{ng} \mathrm{L}^{-1}$, respectively) for a multipoint calibration procedure $\left(\mathrm{R}^{2}>0.998\right)$. The limit of detection, as three times the standard deviation of 10 blank samples, was about $0.1 \mathrm{ng} \mathrm{L}^{-1}$. Additionally, river water reference material with a certified mercury level of $12.6 \pm 1.1 \mathrm{pg} \mathrm{g}^{-1}$ was used as an external standard (ORMS-3, National Research Council Canada). Method recovery was $97 \pm 5 \%$.

Aliquots of filtered $(0.45 \mu \mathrm{m}$ Sartorius) snow samples were analyzed by ion chromatography (Dionex DX120, USA) for major water soluble anions: $\mathrm{F}^{-}, \mathrm{Cl}^{-}, \mathrm{NO}_{3}{ }^{-}$, and $\mathrm{SO}_{4}{ }^{2-}$, and cations: $\mathrm{Na}^{+}, \mathrm{NH}_{4}^{+}, \mathrm{K}^{+}, \mathrm{Mg}^{2+}$, and $\mathrm{Ca}^{2+}$. Conductometric detection was coupled with post-column suppression of eluent ions. The detection limit of the analytical technique was calculated as three times the standard deviation $(3 \sigma)$ of a nearzero concentration measurements. The $\mathrm{pH}$ and electric conductivity (EC) values in all samples were determined at $25^{\circ} \mathrm{C}$, using a portable instrument SevenGo Duo (Mettler Toledo, UK) equipped with an automatic temperature compensation system. The average $\mathrm{pH}$ value was 4.8 , and conductivity varied from 4.8 to $79.2 \mu \mathrm{S} \mathrm{cm}^{-1}$.

Total snowpack thickness corresponded to the depth of snow that was accumulated during a single precipitation event. In Poznań, snow cover thickness varied from 6 to $25 \mathrm{~cm}$ and was significantly lower and less stable compared with the polar snowpack.

\section{Statistical data analysis}

To determine differences in concentrations between collected snow samples, data were checked for normality, outliers, and distribution, using Statistica 10.0 software. Pearson's correlation $(p$ value $<0.05$ ) was used to establish statistically significant correlations between $\mathrm{Hg}$ and major ions in snow samples. A multivariate statistical method FA (Factor Analysis) was used to identify main factors, i.e., sources and processes controlling Hg snow chemistry. Basic meteorological parameters (precipitation, temperature, atmospheric pressure, relative humidity, wind speed, and direction) were provided by the local weather station at the Botanic Garden in Poznań. The regional/macro-regional potential emission sources of $\mathrm{Hg}$ were investigated with 4-day air-mass backward trajectories, generated using archive GDAS meteorological database (spatial resolution $1^{\circ}$ ), with HYSPLIT NOAA model (Draxler and Rolph 2013). Three starting heights of air masses, i.e., 500, 1000 , and $1500 \mathrm{~m}$ were examined, roughly corresponding to daily height of the urban planetary boundary layer.

\section{Results and discussion}

\section{Mercury and major ions in the snow cover from Poznań}

Table 2 shows descriptive statistics for $\mathrm{Hg}$, major ions, $\mathrm{pH}$, and EC in shallow snow cover collected between January and March, 2013, in Poznań. The mean Hg concentration was $4.62 \mathrm{ng} \mathrm{L}^{-1}$ ( \pm 3.12$)$, with maximum of $12.5 \mathrm{ng} \mathrm{L}^{-1}$. In $90 \%$ 
Table 2 Statistical summary of $\mathrm{Hg}$, major ion concentrations, $\mathrm{pH}$, and $\mathrm{EC}$ values, determined in snow samples from Poznań, Poland. Concentrations are given in nanogram per liter $(\mathrm{Hg})$ and milligram per liter (all ions). Abbreviations are as follows: $M D L$ method detection limit, $N$ number of samples, $Q 1$ lower quartile, $Q 3$ upper quartile, percentile 5 and 95. Data were normally distributed

\begin{tabular}{llllllllr}
\hline Species & Avg \pm SD & Min & Max & Median & Q1 & Q3 & $5 \%$ & $95 \%$ \\
\hline $\mathrm{Hg}$ & $4.62 \pm 3.12$ & 0.43 & 12.5 & 3.43 & 2.48 & 6.84 & 0.98 & 10.55 \\
$\mathrm{~F}$ & $0.02 \pm 0.01$ & $<$ MDL & 0.03 & 0.02 & 0.02 & 0.02 & 0.01 & 0.03 \\
$\mathrm{Cl}$ & $0.73 \pm 0.48$ & 0.04 & 2.55 & 0.68 & 0.41 & 0.96 & 0.16 & 1.64 \\
$\mathrm{NO} 3$ & $1.96 \pm 1.49$ & 0.06 & 7.75 & 1.55 & 1.07 & 2.27 & 0.65 & 5.18 \\
$\mathrm{SO} 4$ & $1.24 \pm 1.23$ & 0.05 & 6.35 & 0.85 & 0.43 & 1.58 & 0.11 & 3.32 \\
$\mathrm{Na}$ & $0.11 \pm 0.09$ & $<$ MDL & 0.46 & 0.08 & 0.04 & 0.16 & 0.02 & 0.31 \\
$\mathrm{NH} 4$ & $0.50 \pm 0.41$ & 0.03 & 1.96 & 0.43 & 0.24 & 0.62 & 0.04 & 1.43 \\
$\mathrm{~K}$ & $0.46 \pm 0.47$ & $<$ MDL & 2.52 & 0.36 & 0.05 & 0.67 & 0.02 & 1.31 \\
$\mathrm{Mg}$ & $0.03 \pm 0.04$ & $<$ MDL & 0.26 & 0.02 & 0.01 & 0.04 & 0.01 & 0.10 \\
$\mathrm{Ca}$ & $0.28 \pm 0.31$ & 0.03 & 2.29 & 0.23 & 0.09 & 0.34 & 0.04 & 0.72 \\
$\mathrm{pH}$ & $4.80 \pm 0.41$ & 3.39 & 6.12 & 4.78 & 4.51 & 5.02 & 4.12 & 5.50 \\
\hline
\end{tabular}

of samples of the freshly fallen snow, $\mathrm{Hg}$ concentration was in the range between 0.98 and $10.5 \mathrm{ng} \mathrm{L}^{-1}$.

Mean values of $\mathrm{Cl}^{-}$and $\mathrm{SO}_{4}{ }^{2-}$ were 0.73 and $1.24 \mathrm{mg} \mathrm{L}^{-1}$, respectively. For these ions, the lower quartile was quite similar $\left(\mathrm{Cl}^{-}\right.$and $\mathrm{SO}_{4}{ }^{2-}, 0.41$ and $\left.0.43 \mathrm{mg} \mathrm{L}^{-1}\right)$, but the upper one was statistically different (Table 2). For the other inorganic ions, the concentrations ranged between $0.01 \mathrm{mg} \mathrm{L}^{-1}\left(\mathrm{~F}^{-}, \mathrm{K}^{+}, \mathrm{Na}^{+}, \mathrm{Mg}^{2+}\right)$ and $7.75 \mathrm{mg} \mathrm{L}^{-1}\left(\mathrm{NO}_{3}{ }^{-}\right)$. The median values for the measured ions were in the following order: $\mathrm{NO}_{3}{ }^{-}>\mathrm{SO}_{4}{ }^{2-}>\mathrm{Cl}^{-}>\mathrm{F}^{-}$and $\mathrm{NH}_{4}^{+}>\mathrm{K}^{+}>\mathrm{Ca}^{2+}>\mathrm{Na}^{+}>\mathrm{Mg}^{2+}$ for anions and cations, respectively. The $\mathrm{pH}$ value of snow samples from Poznań varied from 3.93 to 6.12 , with the mean of $4.80( \pm 0.40)$, which was higher than for other urban/industrial sites characterized by elevated concentrations of air pollutants, i.e., $\mathrm{PM}_{10}, \mathrm{PM}_{2.5}, \mathrm{PM}_{1}, \mathrm{CO}$, $\mathrm{BC}, \mathrm{NO}_{\mathrm{x}}, \mathrm{NO}$, and $\mathrm{SO}_{2}$ (EEP report 2015). The mean electric conductivity (EC) was $20.69 \pm 14.01 \mu \mathrm{S} \mathrm{cm}^{-1}$, and the majority of snow samples $(90 \%)$ had EC between 7.07 and $44.9 \mu \mathrm{S} \mathrm{cm}^{-1}$.

\section{Mercury in snow cover-comparison with other sites}

The comparison of $\mathrm{Hg}$ concentrations in snow cover from northern high- and mid-latitude regions is shown in Table 3. Total mercury concentration measured in shallow snow cover from Poznan was significantly lower than in the Canadian Arctic during the AMDEs, i.e., in Alert (121 ng L ${ }^{-1}$, Steffen et al. 2002) and in Resolute (156 ng L ${ }^{-1}$, Lu et al. 2001).

In the present study, surface snow cover was not affected by AMDEs, however characterized by relatively small interseasonal variation of $\mathrm{Hg}$ compared to remote polar sites. In Poznań, distribution of $\mathrm{Hg}$ in snow cover was mainly determined by a local and regional anthropogenic sources (more intense during winter than in other seasons), meteorological situation and long-range transport of pollutants. Mean total Hg concentrations in the snowpack from French mountain stations, i.e., Alp (Ferrari et al. 2002) and Col de Porte (Faïn et al. 2007) were much higher than in Poznań (Table 3). The observations of extremely high $\mathrm{Hg}$ amount in alpine snow samples were linked to local urban plume episodes and atmospheric conditions that enhanced $\mathrm{Hg}$ retention in the snowpack. The Hg concentration range for snow samples from these sites was also higher than for samples from Acadia watersheds in Maine, US (Nelson et al. 2007), where the minimum $\mathrm{Hg}$ value was $2.8 \mathrm{ng} \mathrm{L}^{-1}$ and the maximum was $37.0 \mathrm{ng} \mathrm{\textrm {L } ^ { - 1 }}$. The maximum value of $\mathrm{Hg}$ from our study showed good agreement with the values from sub-arctic sites, i.e., Hudson Bay region (15.4 ng L ${ }^{-1}$, Dommergue et al. 2003). The mean $\mathrm{Hg}$ concentrations in snow cover from the semi-urban site in Poznań were much higher than in snow cover from Mt. Oxford Icefield (0.38 ng L $\left.\mathrm{L}^{-1}\right)$ and Agassiz Ice Cap (0.66 ng L ${ }^{-1}$ )—-high Arctic regions (Zheng et al. 2014). There are also several other $\mathrm{Hg}$ measurements in snow pit from high-altitude sites in Siberian Altai and Swiss Alps (Eyrikh et al. 2003). All these studies showed relatively lower $\mathrm{Hg}$ concentrations in snowpack than those measured in Poznań, with maximum $\mathrm{Hg}$ concentration in

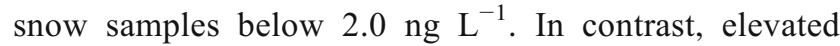
concentrations of total $\mathrm{Hg}$ were observed in glaciers snow from Tibetan Plateau, western China (Zhang et al. 2012) mainly as a result of high atmospheric $\mathrm{Hg}$ loading from regional and global sources. These studies also showed significant seasonal variations of $\mathrm{Hg}$ in snow pits that were much lower in summer than in winter (Zhang et al. 2012).

\section{Hg and other ions' origin in snow cover}

Factor analysis (FA), an orthogonal transformation method with normalized varimax rotation, was applied to the logtransformed database of 12 variables $\left(\mathrm{H}^{+}, \mathrm{EC}\right.$, total $\mathrm{Hg}, \mathrm{F}^{-}$, $\left.\mathrm{Cl}^{-}, \mathrm{NO}_{3}{ }^{-}, \mathrm{SO}_{4}{ }^{2-}, \mathrm{Na}^{+}, \mathrm{NH}_{4}{ }^{+}, \mathrm{K}^{+}, \mathrm{Mg}^{2+}, \mathrm{Ca}^{2+}\right)$, to determine principal components with eigenvalues greater than 1 . The selected factors were then attributed to the main atmospheric 
Table 3 Comparison of mean concentrations of total mercury $\left(\mathrm{n} \mathrm{L} \mathrm{L}^{-1}\right)$ in snow cover from different locations

\begin{tabular}{llll}
\hline Site & Site description & $\begin{array}{l}\text { Hg concentration } \\
\text { range (mean) }\end{array}$ & Reference \\
\hline Poznań, Poland & semi-urban & $0.43-12.49(4.62)$ & This study \\
Gdynia, Poland & coastal/urban & $2.7-22.5(8.6)$ & Siudek et al. 2014 \\
Alp, France & mountain & $13-130$ & Ferrari et al. 2002 \\
Col de Porte, France & mountain & $80-160$ & Faïn et al. 2007 \\
Alert, Canada & remote Arctic, tundra & $5-121$ & Steffen et al. 2002 \\
Acadia, USA & mountain/forest & $2.8-37.0(17.4)$ & Nelson et al. 2007 \\
Siberian Altai, Russia & mountain glaciers & $0.8-1.4$ & Eyrikh et al. 2003 \\
Alps, Switzerland & & $1.5-2.0$ & Zhang et al. 2012 \\
Tibetan Plateau, China & glacier snow & $<1-43.6$ & Dommergue et al. 2003 \\
Hudson Bay, USA & sub-arctic & $4-15.4(10.6)$ & Zheng et al. 2014 \\
Mt. Oxford Icefield Agassiz Ice Cap & glacier, high Arctic & $(0.38)$ & \\
& & $(0.66)$ & \\
\hline
\end{tabular}

processes and sources of pollutants accumulated in the snow cover from Poznań during winter 2013. A three-factor solution of FA explained $73 \%$ of the total variance (Table 4).

Factor FA1 (acidifying pollutants: $\mathrm{H}^{+}, \mathrm{NO}_{3}{ }^{-}, \mathrm{SO}_{4}{ }^{2-}, \mathrm{Na}^{+}$, $\mathrm{NH}_{4}{ }^{+}$, and EC) was a major component of the overall variance (34 \%, Table 4). Factor FA2 indicated four statistically significant variables and contributed $29 \%$ to the total variance. Two industrial pollutants, i.e., $\mathrm{Ca}^{2+}$ and $\mathrm{Mg}^{2+}$, with high loadings of 0.77 and 0.81 , pointed to the transport of fine and coarse particles from different anthropogenic sources, such as construction dust, coal combustion, vehicle emission, and road

Table 4 Factor analysis of inorganic cations, anions, total $\mathrm{Hg}$, and electric conductivity measured in snow cover, Poznań. All variables from the database were log-transformed before mathematical calculations

\begin{tabular}{lccc}
\hline \multirow{2}{*}{ Variables } & \multicolumn{2}{l}{ Factor loading } & \\
\cline { 2 - 4 } & FA1 & FA2 & FA3 \\
\hline $\mathrm{H}^{+}$ & 0.82 & -0.28 & 0.05 \\
$\mathrm{EC}$ & 0.75 & -0.24 & 0.11 \\
$\mathrm{Hg}$ & 0.06 & 0.00 & -0.75 \\
$\mathrm{~F}$ & -0.49 & 0.37 & -0.28 \\
$\mathrm{Cl}$ & 0.06 & 0.87 & -0.08 \\
$\mathrm{NO}_{3}$ & 0.81 & 0.28 & 0.17 \\
$\mathrm{SO}_{4}$ & 0.89 & -0.04 & 0.00 \\
$\mathrm{Na}$ & 0.51 & 0.27 & 0.65 \\
$\mathrm{NH}_{4}$ & 0.84 & 0.18 & -0.15 \\
$\mathrm{~K}$ & -0.21 & 0.87 & -0.11 \\
$\mathrm{Mg}$ & 0.05 & 0.81 & 0.47 \\
$\mathrm{Ca}$ & -0.01 & 0.77 & 0.45 \\
Eigenvalue & 4.08 & 3.43 & 1.22 \\
Percent of variance & 34 & 29 & 10 \\
Cumulative percentage & 34 & 67 & 73 \\
\hline
\end{tabular}

Parameters with high loading $(>0.6)$ were set in italics dust. FA2 factor was also explained by high loading of $\mathrm{Cl}^{-}$ and $\mathrm{K}^{+}(0.87)$. The obtained values suggest strong contribution of acidic inorganic salts from transportation sources (dust, resuspension, traffic) during snow episodes in Poznań. However, other local/regional industrial processes and longrange transport of pollutants cannot be ruled out.

The third factor (10\% of total variance) was characterized by two species with loadings higher than 0.6. Results from FA3 showed that total mercury had statistical significance and inverse correlation with $\mathrm{Na}^{+}$, suggesting some different sources or complex atmospheric processes in which these two components participated. Due to the fact that FA analysis cannot clearly explain the inter-seasonal variability of $\mathrm{Hg}$ in snow cover or $\mathrm{Hg}$ interactions with all variables, some additional data (e.g., meteorological, local/regional atmospheric transport models) and ion molar ratios (i.e., chloride to sulfate, nitrate to sulfate, sulfate to sodium) are needed to assess the role of atmospheric conditions and importance of anthropogenic emission during snow events. These aspects are discussed in the next section.

\section{Vertical distribution of $\mathrm{Hg}$ in snow cover}

Figure 2 illustrates the variation in concentration of total $\mathrm{Hg}$ and ions $\left(\mathrm{NO}_{3}{ }^{-}\right.$and $\left.\mathrm{SO}_{4}{ }^{2-}\right)$ in the snow cover from Poznań. In general, peak concentration of $\mathrm{Hg}$ and major ions did not occur during the same snow episode, suggesting large variability in chemical composition, impact of different industrial/ urban sources, air mass transport, and fluctuations in atmospheric conditions, in particular air temperature and wind speed/direction. High variability in $\mathrm{Hg}$ concentration was found for most snow samples (J1 to J3, F2, M2, and M3). The lowest value occurred in March (M2).

So far, several continuous observations have been undertaken to examine inter-seasonal variability of $\mathrm{Hg}$ in well- 


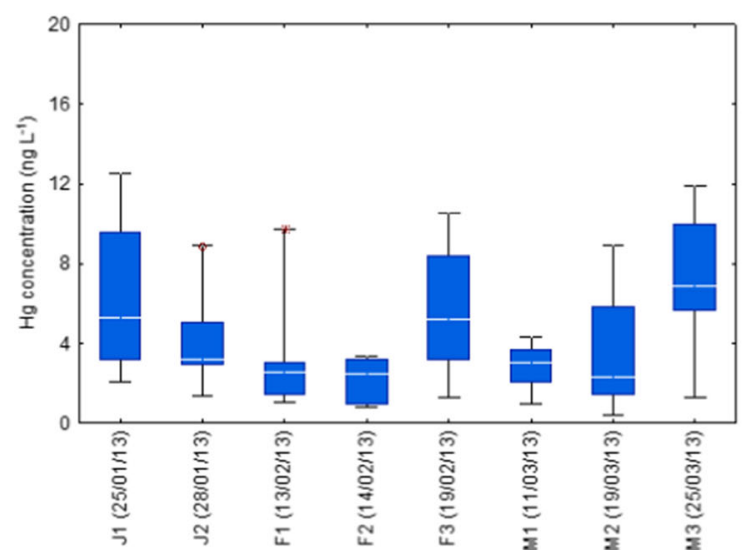

Fig. 2 Box plot of total $\mathrm{Hg}($ left $)$ and $\mathrm{NO}_{3}{ }^{-} / \mathrm{SO}_{4}{ }^{2-}$ (right) concentrations in the snowpack. The inter-seasonal variation in $\mathrm{Hg}$ concentrations was not statistically significant (Kruskal-Wallis test, $p$ value $<0.05$ ). The

stratified polar snowpack (Douglas et al. 2008, Dommergue et al. 2010) and shallow snow cover from mid-latitudes (Siudek et al. 2014). Recent studies carried out in polar environments have documented that $\mathrm{Hg}$ distribution pattern within the snowpack is affected by complex physical processes and heterogeneous chemical reactions with photo-labile halogens such as bromine, bromine monoxide, chlorine, and chlorine monoxide, and is controlled by different meteorological parameters (Steffen et al. 2015). Among these variables, the most important for $\mathrm{Hg}$ retention in snow and/or Hg reemission through air-snow transition layer are cloudiness, air temperature and relative humidity, height of mixing layer, wind speed, solar radiation, snow composition, and type of sites (Johnson et al. 2008, Nelson et al. 2010, Faïn et al. 2013, Angot et al. 2016).

For polluted mid-latitude environments, the most important factors influencing $\mathrm{Hg}$ deposition are the winter maxima of anthropogenic emission and local meteorology. This was observed in Poznań, where vertical concentration profiles of $\mathrm{Hg}$ were very irregular and without general trends during all snow experiments. The distribution of $\mathrm{Hg}$ values measured in snow cover is shown in Fig. 3.

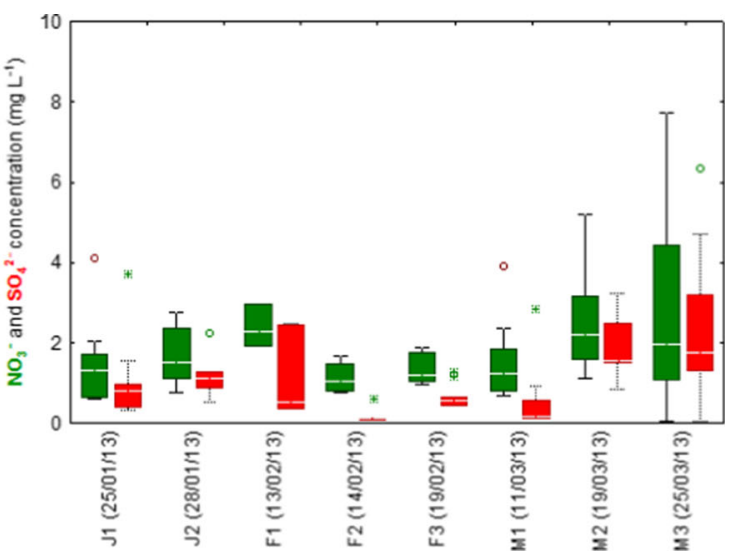

horizontal lines represent median, the box spans - the quartiles, and the whiskers indicate the maximum and minimum values

Different profiles of total $\mathrm{Hg}$ concentration obtained in this study may be linked to specific small-scale processes/sources (mainly local coal combustion) and fast changing atmospheric conditions. For example, the precipitation event on 19 March 2013 (snow depth $=25 \mathrm{~cm}$ ) was associated with very unstable atmospheric conditions, i.e., convective clouds, large gradient of air temperature -4.7 to $4.5^{\circ} \mathrm{C}$, air pressure 1002 $1007 \mathrm{hPa}$, and wind velocity 1.1 to $3.7 \mathrm{~m} / \mathrm{s}$ (Table 1 ). In this case, $\mathrm{Hg}$ concentration correlated well with $\mathrm{NO}_{3}{ }^{-}(0.537, p$ value $=0.351)$, and the mean $\mathrm{NH}_{4}{ }^{+} / \mathrm{SO}_{4}{ }^{2-}$ molar ratio was 0.99. However, $\mathrm{Hg}$ did not show positive correlation with $\mathrm{SO}_{4}{ }^{2-}$, and the $\mathrm{SO}_{4}{ }^{2-} / \mathrm{NO}_{3}{ }^{-}$molar ratio was 0.31 . This suggests lower influence of local $\mathrm{SO}_{2}$ emission on snow chemistry. Filippa et al. (2010) and Puxbaum and Wagenbach (1994) reported higher molar ratios of sulfate-to-nitrate in alpine snowpack, indicating significant impact of continental pollution and specific role of orographic clouds. Nitrate, a marker of anthropogenic emission that typically increases during winter season with decreasing mixing layer height, was a dominant ion in the snowpack from Poznań. Its concentration ranged between 0.68 and $5.18 \mathrm{mg} \mathrm{L}^{-1}$. The abovementioned snow episode (19 March 2013) reflects the

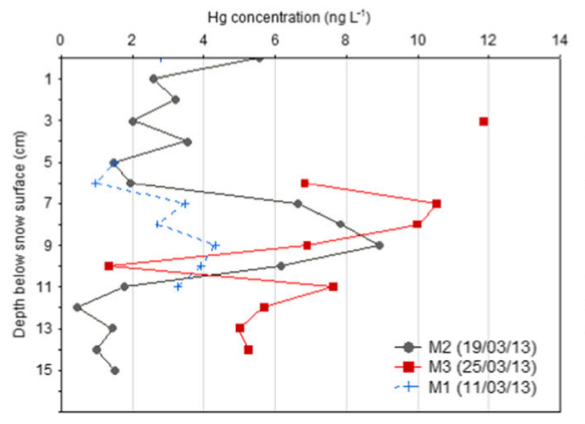

Fig. 3 Vertical profiles of total $\mathrm{Hg}$ concentration $\left(\mathrm{ng} \mathrm{L}^{-1}\right)$ in snow cover. Snow experiments were grouped in three sections based on snow cover thickness. It was as follows: left panel (samples with the largest depth),
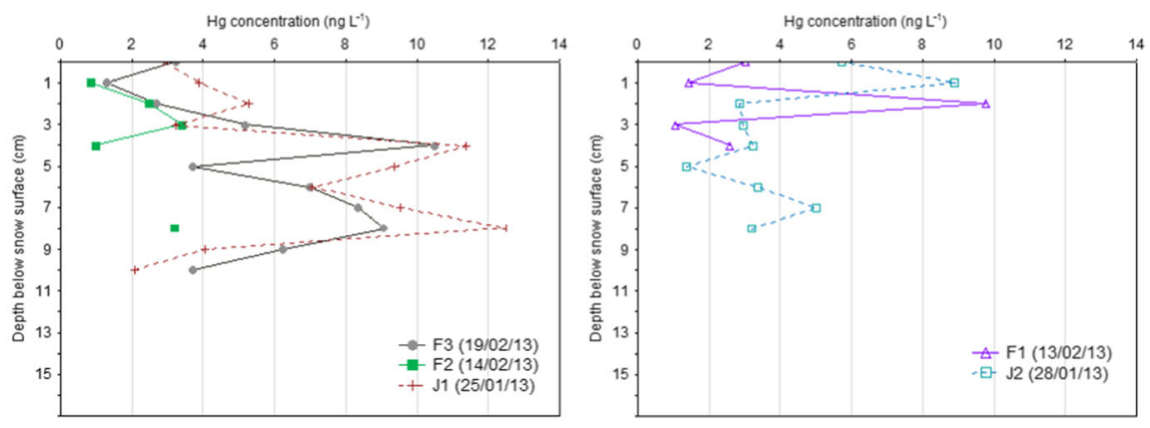

middle (samples with medium depth), and right panel (samples with the lowest depth) 
importance of aqueous/particle-phase reactions of $\mathrm{Hg}$ with acidifying compounds during the below-cloud processes or inside the snowpack after deposition. Moreover, relatively high wind variability, from the southeast to south (Table 1), over a short timescale, explained the predominant contribution of local and regional emissions (i.e., CFFPs Poznań Karolin, metallurgical factory, residential boilers, waste incinerations, rail freight transport, and road traffic). Furthermore, cluster analysis of backward trajectories indicated air masses with pollutants mainly from central and southeastern European industrial hot spots. In contrast to this case, the mean concentration level of $\mathrm{Hg}$ above $5 \mathrm{ng} \mathrm{L}{ }^{-1}$, measured in the snowpack on 25/01 (J1), 19/02 (F3), and 25/03 (M3), was generally attributed to air mass transport from the north-east to northwest (Fig. 2). In addition, during these measurements, wind speed was low (on average $<1.5 \mathrm{~m} / \mathrm{s}$, Table 1 ), indicating relatively inefficient dispersion conditions, probably much more prone to stimulate self-coagulation processes of atmospheric Hg-enriched particles and its deposition with snowfall.

The differences between examples of snow episodes from southern sector (M2 vs. F2) might be partially explained by larger contribution from local fossil fuel combustion (commercial and domestic heating) in samples associated with S-SE airflow compared to the cases attributed to SE-E wind direction. The SE-E areas surrounding Poznań are characterized by significantly lower density of residential buildings and lower influence of local industrial emission and transport. Furthermore, with reference to Table 1, mean air temperature during 14/02 (F2) and 11/03 (M1) snowfalls was -0.4 and $-2.9{ }^{\circ} \mathrm{C}$, respectively, which was lower than on $13 / 02$ and $19 / 03$ (F1 $1.1^{\circ} \mathrm{C}$ and M2 $0.1{ }^{\circ} \mathrm{C}$, respectively). The measurements by Enroth et al. (2016) showed that under low temperature, urban aerosol dynamics can be widely controlled by two main processes, i.e., nucleation and condensation. Therefore, the observed nonlinear shape of $\mathrm{Hg}$ and major ion concentrations in snow cover from Poznań can be regarded as an important proxy for studying changes in atmospheric composition (air quality index, aerosol loading, partitioning processes, sources contribution) and transport (dilution effect, deposition, etc.).

Based on polar snow experiments, it was found that formation of $\mathrm{Hg}^{\circ}$ in the interstitial air inside the snowpack can be mainly initiated by photochemical reduction of divalent mercury species, catalyzed by halogen anions $(\mathrm{Br}, \mathrm{Cl})$ and high level of oxidizing species (Faïn et al. 2007). As expected, due to low or near-zero UV radiation from January to March in Poznań, no statistically significant re-emission of gaseous $\mathrm{Hg}^{\circ}$ from the snowpack to the overlaying atmosphere was observed for the whole snow season. Similar findings were reported by Siudek et al. (2014) for the single coastal site in Gdynia (northern Poland). The study carried out in Gdynia demonstrated preferential mechanism of $\mathrm{Hg}$ retention within the snowpack and direct transfer of $\mathrm{Hg}$ to the soil system during melt season. In addition, high variability of $\mathrm{Hg}$ concentrations in meltwater, ranging from 0.6 to $10.8 \mathrm{ng} \mathrm{L}^{-1}$, with the average value of $4.4 \mathrm{ng} \mathrm{L}^{-1}$, indicated that the significant load of mercury per meter square was retained in the snowpack (Siudek et al. 2014). In contrast, in the present study, we found less variable $\mathrm{Hg}$ concentrations measured in meltwater, which could be linked to substantially lower contribution from local anthropogenic sources observed at this semi-urban station as compared to the coastal site during winter season. Our findings are also consistent with observations from forested and no-canopy sites in the US (Nelson et al. 2008), where large Hg retention was the main pathway of post-depositional processes of $\mathrm{Hg}$ within the snowpack.

\section{Atmospheric long-range transport of mercury}

Figure 4 presents histograms of total $\mathrm{Hg}$ concentration in snow samples as a function of wind sector. Specifically, differences between samples attributed to northerly (N-NE, NW$\mathrm{N}, \mathrm{W}-\mathrm{NW}, \mathrm{NE}-\mathrm{E}$ ) or southerly (SE-S, SE-E) advection were pronounced for the concentration threshold of $4 \mathrm{ng} \mathrm{Hg} \mathrm{L}{ }^{-1}$. In the first backward trajectory cluster, representing mainly northern sources (snow episodes defined as J1, J2, F3, M1, M3, see Table 1), $62 \%$ of values ranged from 4 to $14 \mathrm{ng} \mathrm{L}^{-1}$, whereas for the snow cover associated with southern advection (snow episodes: F1, F2, M2), the histogram was shifted towards lower concentrations (>MDL to $4 \mathrm{ng} \mathrm{L}^{-1}$ ), which did not exceed $10 \mathrm{ng} \mathrm{L}^{-1}$ (Fig. 4). The effect of advection on $\mathrm{Hg}$ concentration in snow samples explains most of its variability and shows large influence of various local/regional anthropogenic sources. Siudek et al. (2015b) have previously studied distribution of trace metals such as $\mathrm{Cu}, \mathrm{Cr}, \mathrm{Cd}, \mathrm{Pb}, \mathrm{Ni}, \mathrm{As}$, and $\mathrm{Zn}$ in snowpack, based on backward trajectory simulations. For northerly and northeasterly airflow, concentrations of $\mathrm{Pb}$, $\mathrm{Zn}$, and $\mathrm{Cr}$ in snow cover were higher. Therefore, the variation in $\mathrm{Hg}$ concentration in freshly fallen snow samples collected after the predominant $\mathrm{N}$ to $\mathrm{NE}$ advection of polluted air masses was probably caused by atmospheric processes and high contribution from the similar sources as in the case of $\mathrm{Pb}, \mathrm{Zn}$, and $\mathrm{Cr}$ (i.e., fossil fuel combustion, traffic-related emission, processing of non-ferrous metals).

In order to better estimate the effect of long-range transport on high $\mathrm{Hg}$ content in the snowpack from Poznań, we examined two clusters representing different types of air masses which transported pollutants over the study domain from south or north directions. Here, we focused specifically on two snow episodes that were representative for each wind sector (Fig. 5).

The first case of below-cloud scavenging of $\mathrm{Hg}$ species by snow was observed on 25 January 2013 (Fig. 5a). It should be highlighted that the above-mentioned snow episode was the first precipitation event after a relatively long period without rain-/snowfalls. A 4-day backward trajectory showed the 

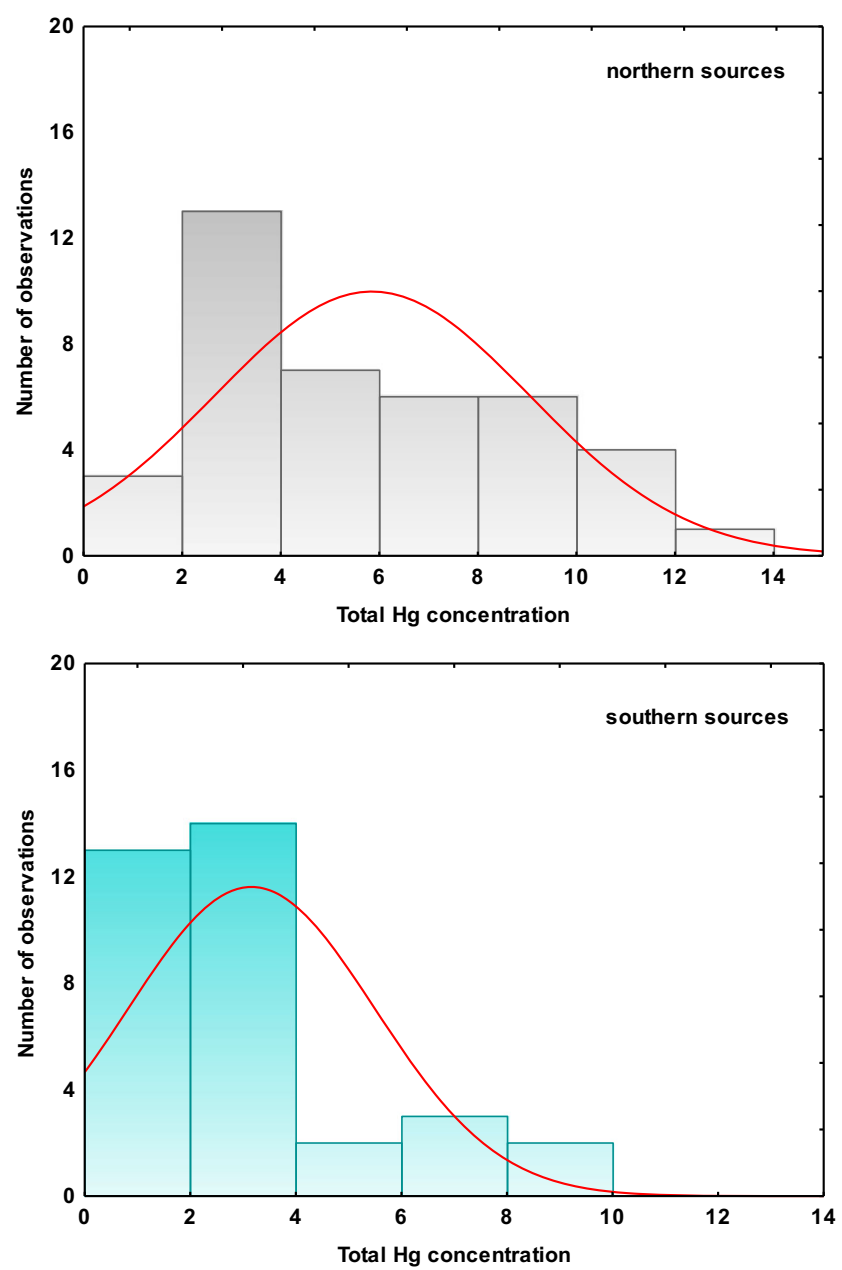

Fig. 4 Frequency distribution of total mercury concentration measured in snow samples associated with a northern $\mathbf{b}$ southern advection during measurements in January-March 2013, Poznań predominance of northerly and northeasterly airflow regime with large precipitation, which revealed major source areas for pollutants accumulated in snow cover in Poznań. They were as follows (in increasing order of importance): northern high latitudes (Greenland, North Atlantic), Scandinavian Peninsula, Baltic Sea, Russia, Lithuania, and northeastern Poland. Due to the fact that urban/industrial emission from polar regions and northern European countries is rather low as compared to central/western Europe, the northern regions had probably minor contribution to the total $\mathrm{Hg}$ pool in snow cover in Poznań. In addition, relatively low wind speeds on 25 January, from 0.1 to $1.1 \mathrm{~m} / \mathrm{s}$, suggested local and regional transport towards the sampling site, from such sources as residential boilers, domestic heating units, fossil fuel combustion in commercial sector, military area in Biedrusko, and waste incineration. Moreover, nocturnal inversion layer might have favored the accumulation of air pollutants and led to higher concentrations of $\mathrm{Hg}$ in the lower atmosphere over the study region just before the $\mathrm{J} 1$ snow experiment. The air temperature during those days was also very low (ranging from -12.4 to $-0.2{ }^{\circ} \mathrm{C}$ ), causing an intensified residential fuel consumption.

The second case was associated with the snow experiment on 19 March (M2), with quite different atmospheric conditions, i.e., air temperature between -4.7 and $4.5^{\circ} \mathrm{C}$, wind speed from 1.1 to $3.7 \mathrm{~m} / \mathrm{s}$ (Table 1). During this experiment, a predominant southeastern to southern advection was observed. Hence, urban plumes from local combustion processes, with minor contribution from long-range transport, were the most probable explanation for elevated $\mathrm{Hg}$ concentrations measured in snow cover. For comparison, the same airflow pattern was observed during F1 experiment (Table 1). However, Hg concentration was slightly higher compared to the case of 19 March. It is important that

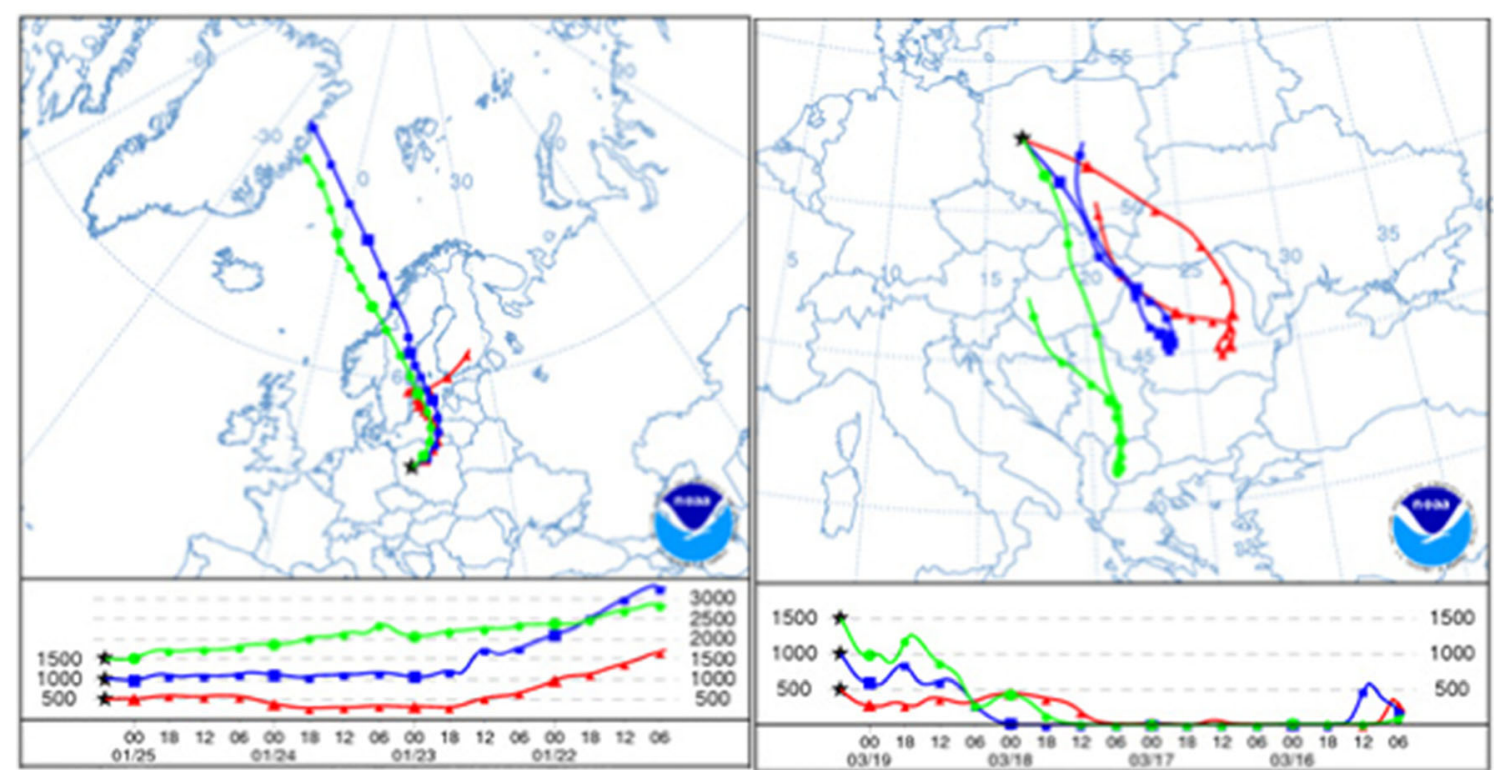

Fig. 5 An example of 4-day backward trajectories for snow cover collected in Poznań on a 25 January 2013 (left) b 19 March 2013 (right). Starting heights of backward trajectories were $500 \mathrm{~m}$ (triangles), $1000 \mathrm{~m}$ (squares), and $1500 \mathrm{~m}$ (circles) 
both snow covers did not include ice layers that might have prevented upward migration of $\mathrm{Hg}$ species through the snowpack, which would greatly affect its chemistry. In addition, snow cover that was formed during F1 experiment was much thicker than that from M2 experiment. Thus, it was not a surprise to notice much quicker $\mathrm{Hg}$ transfer to soil/ground after melting. Nevertheless, the observed differences in $\mathrm{Hg}$ content in snow cover in Poznań were caused not only by inter-seasonal variation in pollutant loadings (residential and commercial sector), but also by a combination of atmospheric chemistry and dynamics.

It can be seen that low temperatures together with the increase in relative humidity largely enhanced $\mathrm{Hg}$ transformation processes in the lower atmosphere, including coagulation and sorption of compounds onto airborne particles (Humphries et al. 2015). Furthermore, such a temperatureinduced mechanism has fundamental impact while considering partitioning between soluble and particulate phase of $\mathrm{Hg}$ (Rutter and Schauer 2007). Several recent studies revealed that the composition of urban aerosol strongly affects vertical profiles of atmospherically deposited $\mathrm{Hg}$ inside the snow cover. However, further observations in urban areas are still needed to provide underpinning data for better understating the role of thick and very unstable snow cover in $\mathrm{Hg}$ chemistry at mid-latitude sites.

\section{Conclusions}

In this study, chemical composition of snow cover was investigated and the results of 3-month field measurements at the semi-urban site in Poznań were thoroughly examined. The applied sampling method was a novel approach and an important criterion for quantitative determination of $\mathrm{Hg}$ in snow cover.

Our results clearly indicated the importance of $\mathrm{Hg}$ measurements in a shallow snow cover of industrially impacted areas in the estimation of local and regional-scale $\mathrm{Hg}$ budget. The inter-seasonal variability of $\mathrm{Hg}$ concentrations in snow cover was mainly driven by two factors: seasonal changes in meteorological conditions (especially fluctuations in ambient temperature and wind pattern) and seasonal variation in $\mathrm{Hg}$ emission from local/regional anthropogenic sources (coal combustion). Based on vertical profiles of $\mathrm{Hg}$ concentration in snow cover, it was found that mercury had relatively irregular distribution, affected by high pollution events due to intensive coal combustion in the study area. In January 2013, we observed a peak in Hg concentrations in snow cover, suggesting large contribution from major anthropogenic point sources located in the vicinity of the study area.

Acknowledgments This work is a part of the postdoctoral project (grant DEC-2012/04/S/ST10/00011) funded by the National Science Center in Poland. The author would like to acknowledge the staff of the
Adam Mickiewicz Botanic Garden in Poznań for meteorological data and also to the NOAA HYSPLIT for data of backward trajectory model. I am very grateful to Prof. J. Siepak and staff from the Department of Water and Soil Analysis for giving me the opportunity to realize this research. Many thanks to I. Kurzyca who provide laboratory space and instrument (maintain/adjust), as well as help in preparing reports from IC analyses in snow samples.

Open Access This article is distributed under the terms of the Creative Commons Attribution 4.0 International License (http:// creativecommons.org/licenses/by/4.0/), which permits unrestricted use, distribution, and reproduction in any medium, provided you give appropriate credit to the original author(s) and the source, provide a link to the Creative Commons license, and indicate if changes were made.

\section{References}

Angot H, Magand O, Helmig D, Ricaud P, Quennehen B, Gallée H, Del Guasta M, Sprovieri F, Pirrone N, Savarino J, Dommergue A (2016) New insights into the atmospheric mercury cycling in Central Antarctica and implications at a continental scale. Atmos Chem Phys. doi:10.5194/acp-2016-144

De Simone F, Gencarelli CN, Hedgecock IM, Pirrone N (2014) Global atmospheric cycle of mercury: a model study on the impact of oxidation mechanisms. Environ Sci Pollut Res 21:4110-4123

Dommergue A, Ferrari CP, Gauchard P-A, Boutron CF, Poissant L, Pilote M, Jitaru P, Adams FC (2003) The fate of mercury species in a subarctic snowpack during snowmelt. Geophys Res Letters 30:16211624

Dommergue A, Larose C, Faï X, Clarisse O, Foucher D, Hintelmann H, Schneider D, Ferrari CP (2010) Deposition of mercury species in the Ny-Ålesund area (79 degrees N) and their transfer during snowmelt. Environ Sci Technol 1(44):901-907

Douglas T, Sturm M, Simpson W, Blum J, Alvarez-Aviles L, Keeler G, Perovich D, Biswas A, Johnson K (2008) The influence of snow and ice crystal formation and accumulation on mercury deposition to the Arctic. Environ Sci Technol 42:1542-1551

Draxler RR, Rolph GD (2013) HYSPLIT (HYbrid Single-Particle Lagrangian Integrated Trajectory) Model access via NOAA ARL READY Website. NOAA Air Resources Laboratory, College Park. http://www.arl.noaa.gov/HYSPLIT.php)

EEP report (2015) Air quality in Europe-2015 report. 5:1-64. doi: $10.2800 / 62459$

Engelhard C, De Toffol S, Lek I, Rauch W, Dallinger R (2007) Environmental impacts of urban management - the alpine case study of Innsbruck. Sci Total Environ 32:286-294

Enroth J, Saarikoski S, Niemi J, Kousa A, Ježek I, Mocnik G, Carbone S, Kuuluvainen H, Rönkkö T, Hillamo R, Pirjola L (2016) Chemical and physical characterization of traffic particles in four different highway environments in the Helsinki metropolitan area. Atmos Chem Phys 16:5497-5512

Eyrikh S, Schwikowski M, Gägeller W, Tobler L, Papina T (2003) First mercury determination in snow from high-mountain sites in the Siberian Altai and Swiss Alps as reflection of present atmospheric concentration of $\mathrm{Hg}$. In: 7th International Conference on Mercury as a Global Pollutant, p. 1551-1555

Faï X, Grangeon S, Bahlmann E, Fritsche J, Obrist D, Dommergue A, Ferrari CP, Cairns W, Ebinghaus R, Barbante C, Cescon P, Boutron $C$ (2007) Diurnal production of gaseous mercury in the alpine snowpack before snowmelt. J Geophys Res 112:1-12

Faïn X, Helmig D, Hueber J, Obrist D, Williams MW (2013) Mercury dynamics in the Rocky Mountain, Colorado, snowpack. Biogeosciences 10:3793-3807 
Ferrari CP, Dommergue A, Veysseyre A, Planchon F, Boutron CF (2002) Mercury speciation in the French seasonal snow cover. Sci Total Environ 15(287):61-69

Filippa G, Frappaz M, William MW, Zanini E (2010) Major element chemistry in inner alpine snowpack (Aostra Valley Region, NW Italy). Cold Region Sci and Technol 64:158-166

Humphries RS, Schofield R, Keywood MD, Ward J, Pierce JR, Gionfriddo CM, Tate MT, Krabbenhoft DP, Galbally IE, Molloy SB, Klekociuk AR, Johnston PV, Kreher K, Thomas AJ, Robinson AD, Harris NRP, Johnson R, Wilson SR (2015) Boundary layer new particle formation over East Antarctic sea ice-possible Hg-driven nucleation? Atmos Chem Phys 15:13339-13364

Johnson KP, Blum JD, Keeler GJ, Douglas TA (2008) Investigation of the deposition and emission of mercury in arctic snow during an atmospheric mercury depletion event. J Geophys Res 113:D17304

Lahoutifard N, Sparling M, Lean D (2005) Total and methyl mercury patterns in Arctic snow during springtime at Resolute, Nunvaut, Canada. Atmos Environ 39:7597-7606

Larose C, Prestat E, Cecillon S, Berger S, Malandain C, Lyon D, Ferrari C, Schneider D, Dommergue A, Vogel TM (2013) Interactions between snow chemistry, mercury inputs and microbial population dynamics in an Arctic snowpack. PLoS One 8(11):e79972. doi:10.1371/journal.pone.0079972

Li C, Zhang Q, Kang S, Liu Y, Huang Y, Liu X, Guo J, Wang K, Cong Z (2015) Distribution and enrichment of mercury in Tibetan lake waters and their relations with the natural environment. Environ Sci Pollut Res 16:12490-12500

Liu Y, Chai X, Hao Y, Gao X, Lu G, Zhao Y, Zhang J, Cai M (2015) Total mercury and methylmercury distributions in surface sediments from Kongsfjorden, Svalbard, Norwegian Arctic. Environ Sci Pollut Res 11:8603-8610

Lu J, Schroeder WH, Barrie L, Steffen A, Welch H, Martin K, Lockhart L, Hunt R, Boila G, Richter A (2001) Magnification of atmospheric mercury deposition to polar regions in springtime: the link to tropospheric ozone depletion chemistry. Geophys Res Letter 28:32193222

Nelson SJ, Johnson KB, Kahl JS, Haines TA, Fernandez IJ (2007) Mass balances of mercury and nitrogen in burned and unburned forested watersheds at Acadia National Park, Maine, USA. Enivorn Monit Assess 126:69-80

Nelson SJ, Johnson KB, Weathers KC, Loftin CS, Fernandez IJ, Kahl JS, Krabbenhoft DP (2008) A comparison of winter mercury accumulation at forested and no-canopy sites measured with different snow sampling techniques. Appl Geochem 23:384-398

Nelson SJ, Fernandez IJ, Kahl JS (2010) A review of mercury concentration and deposition in snow in eastern temperate North America. Hydrolog Process 24:1971-1980
Puxbaum H, Wagenbach D (1994) High alpine precipitation chemistry. In: Borell PM et al. (eds) The proceedings of EUROTRAC symposium 1994. SPB Academic Publishing bv, The Hague, pp. $597-605$

Rutter AP, Schauer JJ (2007) The effect of temperature on the gas-particle partitioning of reactive mercury in atmospheric aerosols. Atmos Environ 41:8647-8657

Siudek P, Falkowska L, Frankowski M, Siepak J (2014) An investigation of atmospheric mercury accumulated in the snow cover from the urbanized coastal zone of the Baltic Sea, Poland. Atmos Environ 95:10-19

Siudek P, Falkowska L, Brodecka A, Kowalski A, Frankowski M, Siepak J (2015a) Mercury in precipitation over the coastal zone of the southern Baltic Sea, Poland. Environ Sci Pollut Res 22(4):25462557

Siudek P, Frankowski M, Siepak J (2015b) Trace element distribution in the snow cover from an urban area in central Poland. Environ Monit Assess 187(5):225. doi:10.1007/s10661-015-4446-1

Siudek P, Kurzyca I, Siepak J (2016) Atmospheric deposition of mercury in central Poland: sources and seasonal trends. Atmos Res 170:14 22

Steffen A, Schroeder WH, Bottenheim J, Narayana J, Fuentes JD (2002) Atmospheric mercury concentrations: measurements and profiles near snow and ice surface in the Canadian Arctic during alert 2000. Atmos Environ 36:2653-2661

Steffen A, Lehnherr I, Cole A, Ariya P, Dastoor A, Durnford D, Kirk J, Pilote M (2015) Atmospheric mercury in the Canadian Arctic. Part I: a review of recent field measurements. Sci Total Environt 509-510: $3-15$

US EPA method 1631 (2002) Revision E: mercury in water by oxidation, purge and trap, and cold vapor atomic fluorescence spectrometry

Wiener JG, Krabbenhoft DP, Heinz GH, Scheuhammer AM (2003) Ecotoxicology of mercury. In: Hoffman DJ, Rattner BA, Burton GA, Cairns JS (eds) Handbook of ecotoxicology. Lewis Publ, Boca Raton, pp. 409-463

Witherow R, Lyons WB (2008) Mercury deposition in polar desert ecosystem. Environ Sci Technol 42:4710-4716

Zhang Q, Huang J, Wang F, Mark L, Xu J (2012) Mercury distribution and deposition in glacier snow over western China. Environ Sci Technol 46:5404-5413

Zheng J, Pelchat P, Vaive J, Bass D, Ke F (2014) Total mercury in snow and ice samples from Canadian High Arctic ice caps and glaciers: a practical procedure and method for total $\mathrm{Hg}$ quantification at low $\mathrm{pg} /$ g level. Sci Total Environ 468-469:487-494. doi:10.1016/j. scitotenv.2013.08.078 